\title{
Identitas kepemilikan pura dalam hubungan dengan perkembangan pariwisata dan konflik sosial di Bali
}

\author{
The identity of temple ownership in the relation with tourism development \\ and social conflict in Bali
}

\author{
GPB Suka Arjawa \\ Prodi Sosiologi, Fakultas Ilmu Sosial dan Ilmu Politik, Universsitas Udayana. Jalan PB \\ Sudirman, Denpasar 80361 Indonesia. Telepon: (361) 701954, 704845. \\ E-mail: suka_arjawa@yahoo.com
}

\begin{abstract}
Social conflict in Bali frequently involves public prayer area (Pura), can last in several days and leads to disputes between family within same community. Therefore, the community who perform prayer in the Pura was prone to disengagement caused by conflict. The purpose of this article was to understand the relations between social conflict in Bali which related to ownership social identity and tourism development in Bali. The research method used to approach was conducted in qualitative way in order to shows positive correlations between social changes and the conflicts. The social change in Bali was caused by economic factor to the social tradition factor, directly faced with identity in each community which have responsibility to protect the temple. Tourism is the basic factor for the social change in Bali. Tourist industry make the existence of hotel and restaurant increased. By the local goverment, the tax of these hotel and restaurant were allocated a fund for desa pakraman, the locus of cultural tourism in Bali. But in any cases, most of community members in desa pakraman make a decision to use this fund to develop the temple. Different opinion in community to use this fund could cause a conflict because the community in this temple has different identity.
\end{abstract}

Keywords: social conflict, identity, social change

\begin{abstract}
Abstrak
Konflik sosial yang terjadi di Bali seringkali melibatkan tempat sembahyang (Pura), dapat berlangsung berharihari dan dapat berujung pada perpecahan hubungan antar keluarga yang berada di dalam satu komunitas. Akibatnya, komunitas yang melakukan persembahyang di Pura tersebut bisa pecah sebagai akibat dari konflik. Tujuan penelitian ini adalah untuk mengetahui bagaimana hubungan antara konflik sosial yang ada di Bali yang berkaitan dengan identitas sosial kepemilikan pura dan perkembangan pasriwisata di Bali. Metode penelusuran di daerah konflik itu dilaksanakan secara kualitatif guna memperlihatkan bahwa ada hubungan positif antara perubahan sosial dengan konflik-konflik yang terjadi itu. Dilakukan kunjungan ke lapangan, dialog dengan anggota masyarakat, serta dicatat secara geografis posisi tempat sembahyang serta lokasi konflik yang ada. Berbagai fenomena yang didapatkan di lapangan dicatat dan direkam, dan kemudian ditafsirkan untuk mendapatkan simpulan. Perubahan sosial yang dimaksud adalah masuknya unsur ekonomi ke dalam unsur tradisi masyarakat yang kemudian berbenturan dengan identitas komunitas yang memiliki tempat sembahyang tersebut. Di sisi lain, perkembangan pariwisata memberikan sumbangan terhadap berdirinya berbagai hotel dan restoran. Pajak hotel dan restoran inilah kemudian yang disumbangkan kepada desa pakraman, yang merupakan lokus dari pariwisata budaya Bali. Oleh sebagian besar masyarakat, sumbangan ini dipakai untuk memperbaiki tempat sembahyang. Artikel ini menyimpulkan bahwa pertentangan antara kelompok masyarakat dalam penggunaan sumbangan inilah yang memicu konflik sosial di Bali karena komunitas yang sembahyang di pura tersebut, terdiri dari berbagai kelompok yang mempunyai identitas tersendiri.
\end{abstract}

Kata Kunci: konflik sosial, identitas, perubahan sosial

\section{Pendahuluan}

Pura merupakan tempat suci bagi masyarakat Hindu Bali. Di tempat ini warga Hindu Bali melaksanakan persembahyangan, baik sehari-hari maupun dalam berbagai jenis persembahyangan 
yang diselenggarakan. Masyarakat Hindu Bali mempunyai beragam jenis persembahyangan yang bisa juga disebut dengan yadnya. Perubahan sosial yang terjadi seringkali menimbulkan perbedaan pendapat yang muncul dari tempat persembahyangan ini sehingga menimbulkan konflik cukup intens di masyarakat. Beberapa konflik itu bahkan sampai menimbulkan perpecahan banjar maupun keluarga. Banjar adalah komunitas keluarga yang merupakan struktur paling bawah dari organisasi sosial tradisional di Bali. Mirip dengan rukun tetangga di Jawa.

Perubahan sosial yang terjadi di Bali, tidak bisa dilepaskan dari berkembangnya pariwisata sejak dekade 70-an. Tempat yang sebelumnya dipandang kering tidak berpenghasilan, berkembang menjadi daerah pariwisata. Area pura yang dipandang suci, berkembang menjadi daerah industri. Pura yang sebelumnya sederhana dengan bantuan dana dari pemerintah daerah dikembangkan menjadi lebih mewah. Sementara itu keberadaan pura tidak bisa dilepaskan dari identitas masyarakat. Identitas ini bermacam-macam, mulai dari keturunan, kelas, sampai dengan kasta. Perkembangan-perkembangan seperti inilah yang membuat konflik bisa muncul karena tidak adanya kesepakatan-kesepakatan diantara pengampu tempat sembahyang tersebut.

Dalam kasus di Banjar Gereseh di Kecamatan Marga, Kabupaten Tabanan misalnya, penggembokan pura justru membuat konflik antar warga dengan keluarga di komunitas setempat. Di Pangkungkarung, Tabanan, pembangunan Pura Khayangan Tiga menyebabkan perpecahan pada komunitas banjar. PuraKhayanganTiga, merupakan tempat sembahyang bagi kumpulan banjar-banjar yang membentuk kesatuan desa. Ada tiga pemujaan disini, yaitu tempat memuja Brahma.Di Kabupaten Gianyar persaudaraan antara komunitas Brahmana menjadi terpecah karena saling klaim kepemilikan pura. Banyak lagi kasus-kasus yang menyinggung pura sebagai pemicu dari konflik yang terjadi di beberapa tempat di Bali. Keberadaan pura tidak menimbulkan konflik, tetapi sikap, cara pandang serta berbagai penafsiran tentang keberadaan pura akibat dari faktor-faktor perubahan sosial itulah yang membuat masyarakat kurang terkendali. Solidaritas yang disebabkan oleh identitas yang melekat pada masyarakat sering membuat tindakan massif, di mana pura hanya dijadikan sebagai obyek untuk menyudutkan kelompok lain.

Tulisan ini mencoba melihat fenomena konflik dengan melihat pura sebagai bagiannya. Apakah yang menjadi faktor penyebab konflik yang terkait dengan pura? Apakah konflik ini disebabkan oleh keberadaan pura atau sikap masyarakatnya? Bagaimana kemudian pemecahan terhadap konflik tersebut?

\section{Metode Penelitian}

Penelitian ini dilakukan dengan metode kualitatif. Penelusuran di lapangan melalui metode ini dengan tujuan lebih memahami apa yang menjadi kenyataan di lapangan beserta maksud dan makna yang ada di balik peristiwa tersebut. Dalam penelitian ini, dilakukan kunjungan ke lapangan, berdialog dengan anggota masyarakat, serta secara geografis tentang posisi tempat sembahyang serta lokasi konflik yang ada. Berbagai fenomena yang didapatkan di lapangan dicatat dan direkam, dan kemudian ditafsirkan untuk mendapatkan simpulan sesuai dengan tujuan penelitian.

Wawancara dengan narasumber dilakukan di tahun 2012 dan tahun 2013, terutama yang mengalamai kasus konflik. Disamping itu peningkatan jumlah uang pajak restoran yang meningkat di tahun 2013, membuat wawancara juga dilakukan tahun ini. Penelitian dilakukan di Banjar Pakudui, Gianyar, Banjar Tegallingah Gianyar, Banjar Pangkungkarung, Tabanan serta dalam konflik yang penyelesaiannya lebih cepat, dilakukan di Banjar Gereseh, Tabanan. Informasi yang ada di media massa, diperiksa ke lapangan dan berita media massa itu memberikan petunjuk untuk masuk ke daerah konflik. 


\section{Hasil dan Pembahasan}

Dalam konteks agama Hindu di Bali, pura adalah tempat persembahyangan. Secara garis besar sesuai dengan sejarah yang dibentuk oleh Mpu Kuturan pada abad ke-11, pura di Bali hanya ada dua, yakni tempat persembahyangan untuk keluarga, dan pura untuk persembahyangan yang digunakan oleh masyarakat (Tohjaya 1991:8). Semuanya ini merupakan bentuk penyederhanaan dari berbagai sekte yang ada di Bali pada waktu itu. Mpu Kuturan, sebagai filsuf Hindu ingin mencegah konflik antar sekte di Bali yang jumlahnya belasan pada waktu itu. Maka, pada tingkat keluarga dibentuklah tempat sembahyang yang disebut Rong Tiga, yang makna harafiahnya adalah tiga ruangan, merupakan manifestasi bagi Brahma (Tuhan Pencipta), Wisnu (Tuhan Pemelihara) dan Siwa sebagai manifestasi Tuhan dalam fungsinya sebagai pelebur. Masyarakat Hindu Bali menyebutnya dengan kemulan, berasal dari kata mula, artinya asal.

Pada tingkat masyarakat, tempat sembahyang disebut Khayangan Tiga, maknanya kurang lebih tiga wujud tempat persembahyangan. Sama seperti Rong Tiga, Khayangan Tiga ini terdiri dari tiga tempat persembahyangan, yaitu Pura Desa sebagai manifestasi Brahma. Kemudian Pura Puseh sebagai manifestasi Wisnu dan Pura Dalem. Pura yang terakhir ini merupakan manifestasi Siwa (Warren 1993:142). Hanya dua jenis pura inilah secara garis besar ada pada masyarakat Hindu di Bali, dan telah dikonsepsikan sejak abad ke-11. Dalam perkembangan sosial budaya di Bali, Pura Khayangan Tiga inilah yang dipakai syarat untuk membentuk Desa Pakraman, yakni komunitas Hindu untuk menyembah Tuhan di dalam satu Khayangan Tiga tersebut.

Perkembangan sosial selanjutnya di Bali memunculkan berbagai macam pura lagi. Pada tingkat keluarga besar, didirikanlah tempat sembahyang yang disebut dengan Pura Dadia. Pura Dadia, adalah sebutan untuk pura keluarga yang satu keturunan. Sebutan lainnya dari pura ini adalah Paibon dan Panti. Paibon juga merupakan sebutan untuk tempat sembahyang keluarga yang dari satu keturunan. Pura Panti, juga merupakan sebutan untuk tempat sembahyang satu keturunan tetapi lebih sering bagi kelompok yang berasal dari warna Sudra. Intinya adalah tempat sembahyang yang berasal dari satu keturunan. Komunitas pedagang juga membuat tempat sembahyang yang disebut dengan Pura Melanting. Pura Melanting, merupakan tempat sembahyang yang didirikan oleh komunitas pedagang. Pura ini didirikan di daerah strategis dimana terdapat banyak aktivitas perdagangan. Sementara itu, di komunitas banjar, yakni komunitas kumpulan dari keluarga-keluarga yang menempati wilayah tertentu, juga mendirikan tempat persembahyangan bersama. Pada komunitas banjar ritual-ritual tersebut berlangsung (Warren 1993:2). Sebutan pura ini tergantung dari komunitas banjar bersangkutan untuk menyebutnya.

Di samping pura atau tempat sembahyang yang disebutkan itu, beberapa kerajaan di Bali juga mempunyai tempat persembahyangan tersendiri. Pura ini dipakai untuk sembahyang bagi anggota keluarga kerajaan, beserta dengan rakyat yang berada di lingkungan kerajaan tersebut. Bekas kerajaan Mengwi misalnya, mempunyai Pura yang disebut dengan Taman Ayun. Dalam pandangan Nordholt (2009:94) pura ini menghubungkan tiga unsur yaitu leluhur dinasti Mengwi; ikatan dengan dewa-dewa gunung, pusat kerajaan dan laut; dan penghormatan untuk menjamin kesuburan dan keberlangsungan pertanian. Sebenarnya pura ini juga terdiri dari perwakilan tempat sembahyang berbagai tempat sembahyang besar yang ada di Bali.

Seperti juga tempat sembahyang umat lainnya, pura bagi masyarakat Hindu di Bali mempunyai makna yang khusus. Makna tersebut yang paling utama terletak pada fungsinya untuk menghubungkan manusia dengan sang Pencipta. Karena itu dari sisi tempat, bentuk, penampilan sampai dengan ornamennya mempunyai pilihan tersendiri. Pura pada tingkat keluarga mempunyai tempat khusus, yaitu pada lokasi yang paling utama dalam tataran lokasi perumahan. Pura menempati lokasi paling timur, bertepatan dengan terbitnya matahari. Atau bisa juga menempati posisi timur laut, orientasi dari Gunung Agung. Inilah posisi paling utama bagi masyarakat Hindu di Bali (Nordholt 2009:22). Pura Khayangan Tiga juga mempunyai lokasi pilihan bagi masyarakat. Pura ini 
dimiliki oleh desa pakraman, yang kemungkinan anggotanya banyak banjar sehingga Pura Khayangan Tiga terletak di banjar yang paling strategis.

Dalam konteks kebudayaan Bali, pura mempunyai bentuk yang memenuhi tiga syarat ruangan, yaitu ruangan utama (utama mandala), di mana pada ruangan ini terdapat bangunan-bangunan utama untuk persembahyangan. Kemudian ruangan tengah (madya mandala), yang difungsikan untuk berdirinya bangunan-bangunan penunjang. Bangunan ini mempunyai fungsi sosial, yakni untuk mendukung kegiatan dalam pelaksanaan upacara. Masyarakat membuat perlengkapan upacara pada ruangan ini, sedangkan nista mandala (ruangan luar) adalah ruangan pintu masuk, atau ruang luar dari areal pura. Dalam ruangan ini masyarakat bisa membersihkan diri (misalnya, membasuh muka) sebelum memasuki areal pura. Bentuk ini umumnya dipakai oleh pura yang dimiliki oleh masyarakat. Akan tetapi, tempat persembahyangan keluarga, bentuk ruangan seperti ini tidak seluruhnya bisa didapatkan. Karena itu, hanya di buat ruangan utama dan ruang nista.

Bangunan tempat persembahyangan di Bali sangat dipengaruhi oleh kelas dan struktur sosial yang ada. Pengaruh ini akan terlihat pada ornamen-ornamen yang ada di dalam pura tersebut. Meskipun sesungguhnya kasta yang ada di Bali itu berkembang dari warna, yaitu pembagian sosial sesuai dengan profesi dalam masyarakat [yaitu sebagai penghubungan masyarakat dengan Tuhan (Brahmana), profesi sebagai pegawai atau tentara (Ksatria), profesi sebagai pedagang (Wesya), dan profesi sebagai petani (Sudra)], akan tetapi secara sosial warna itu sudah terlanjur dimengerti sebagai kelas sosial. Maka masing-masing pura tersebut mempunyai ciri-ciri dan ornamen tersendiri. Kelas sosial tersebut juga bisa dilihat dari masyarakat Bali asli, yang disebut-sebut sebagai Bali Aga, dan masyarakat Bali keturunan Majapahit. Ornamen dari masing-masing pura ini berbeda. Misalnya masyarakat keturunan Majapahit sering memakai tanduk menjangan sebagai penghias puranya. Demikian pula dengan masyarakat yang memandang dirinya sebagai bagian dari keturunan kerajaan di masa lalu.

Secara struktural, masyarakat bisa dibedakan menjadi masyarakat kelas ekonomi mampu dan kurang mampu. Struktur sosial ini mempengaruhi juga penampilan dan ornamen tempat persembahyangan, baik untuk pura keluarga maupun masyarakat. Ornamen dan bentuk dari tempat sembahyang dikaitkan dengan struktur masyarakat seperti ini mudah dilihat dari penampilan luarnya. Misalnya dengan memakai lantai semen, ukir-ukiran pada sebagaian besar bangunan, bersih, dan berbagai indikator yang memperlihatkan kemewahan. Bangunan pura seperti ini bisa dikatakan dimiliki oleh keluarga, kelompok atau masyarakat dari golongan ekonomi mampu.

Kendati demikian, khususnya pura yang dimiliki oleh masyarakat, bangunan pura bisa dimungkinkan mewah, diatas rata-rata karena pembiayaannya berasal dari sumbangan masyarakat secara bertahap. Inilah yang membuat bangunan tempat persembahyangan itu lebih mewah dibanding dengan rata-rata kemampuan ekonomi dari masyarakat dimana pura itu berdiri. Pura mempunyai identitas tersendiri bagi masyarakat yang memilikinya. Pura merupakan cerminan asal-usul, kelas sosial, struktur sosial dari masyarakat. Identitas ini kemudian mempunyai pengaruh-pengaruh yang cukup besar dalam hubungan sosial selanjutnya. Seperti yang diungkapkan oleh Engel \& Munger yang dikutip oleh Beckmann \& Beckmann (2011:21) identitas seseorang adalah hasil dari proses identifikasi yang muncul dalam relasi sosial. Identitas juga memungkinkan orang untuk menceritakan sehari-hari relasinya serta mengaitkan dengan cerita-cerita masa lalu. Dalam konteks demikian, identitas kolektif mempunyai makna normatif dan kognitif. Artinya sebagai cara untuk memahami diri dan membentuk norma-norma perilaku. Identitas kolektif yang juga disebut katagoris berfungsi untuk mengidentifikasi seseorang, individu, kelompok, relasi dan lembaga (Beckmann \& Beckmann 2011:19).

Pura dalam konteks demikian bisa dikatakan sebagai tempat sosialisasi, yang kemudian membuat pura ini menjadi identifikasi bagi individu maupun kelompok. Berger (1994) menyebutkan bahwa proses sosialisasi itu melalui tiga tahap yang pada akhirnya membentuk sikap seseorang. Proses itu adalah eksternalisasi, obyektivasi, dan internalisasi. Eksternalisasi adalah pencurahan kedirian manusia secara terus-menerus ke dalam dunia baik aktifitas fisis maupun mental. Obyektivasi adalah 
disandangnya produk-produk aktivitas itu (baik fisik maupun mental), suatu realitas yang berhadapan dengan para produsennya semula, dalam bentuk suatu kefaktaan yang eskternal, dan lain dari para produser itu sendiri. Internalisasi adalah peresapan kembali realitas tersebut oleh manusia, dan mentransfernya sekali lagi dari struktur-struktur dunia obyektif ke dalam struktur-struktur kesadaran subyektif (Berger 1994:5).

Pura, dengan berbagai ritual yang berlangsung setiap enam bulan sekali itu, adalah eksternalisasi yang merupakan pencurahan kedirian manusia secara terus-menerus. Dalam konteks religiusitas di Bali, ritual tidak hanya merupakan aktivitas tunggal, tetapi mempunyai rentetan dengan ritual sosial yang lain. Sebelum upacara puncak diselenggarakan, ritual sosial seperti gotong royong menjadi bagian dari kegiatan masyarakat. Hal ini selalu melintasi batas waktu dan ruang. Artinya itu bisa berulang setiap enam bulan di tempat yang sama. Atau terulang lagi pada waktu yang berbeda di tempat yang berbeda, manakala wilayah itu mempunyai lebih dari satu tempat persembahyangan. Dari ritual sosial inilah muncul konsepsi budaya gotong royong Bali yang disebut dengan segalak seguluk salunglu sebayantaka, yakni bertindak bersama-sama dalam keadaan senang maupun menghadapi maut (Purwita 1993:37)

Konsepsi budaya inilah yang melekat pada masyarakat Hindu di Bali. Berbagai ritual yang dijalankan memerlukan perlengkapan yang harus dibuat secara bersama-sama. Tujuan tindakan bersama-sama ini adalah untuk meringankan biaya, waktu dan tenaga. Gotong-royong selalu dilakukan sebelum adanya upacara inti. Gotong royong ini terbentuk sebagai solidaritas mekanis, dimana setiap komunitas yang ikut sembahyang di pura tersebut harus terlibat. Tidak ikut sertanya seseorang akan bermakna pelanggaran yang seringkali dikenakan denda atau hukuman, baik dalam bentuk sosial maupun dana. Perwujudan gotong-royong bisa dalam wujud pembersihan bersama-sama, membuat sesajen bersama-sama dan berbagai keperluan upacara ini. Baik laki-laki maupun perempuan akan mempersembahkan kemampuanya dalam melakukan kerja. Dalam hal wanita Bali, konteks pembuatan perlengkapan upacara mempunyai kesibukan lebih besar. Ini terkait dengan keterampilan wanita Bali dalam membuat perlengkapan tersebut, terutama dalam hal canang. Dalam catatan Nakatani (2005:127), beberapa wanita Bali mampu membuat perlengkapan ini (canang), antara 25 sampai 75 per hari.

Pada akhirnya segala kegiatan tersebut merupakan eskternalisasi dari budaya Hindu Bali, yang kemudian diobyektivasi oleh anggota masyarakat, terutama generasi baru. Itulah yang kemudian membentuk internalisasi. Artinya segenap rangkaian upacara itu dipercaya oleh masyarakat sebagai bagian dari budaya dan kebiasaannya, yang harus dilakukan di Pura tersebut. Pura menjadi tempat untuk melakukan segala ritual itu dan kemudian menjadikannya sebagai sebuah kepercayaan.

Identifikasi individu maupun kelompok muncul dari kegiatan seperti ini. Kegiatan yang berulang terus-menerus setiap enam bulan, atau bakan lebih singkat dari itu merupakan peritiwa yang mendekatkan kelompok atau masyarakat terhadap pura dengan segala aktivitasnya. Generasi terdahulu akan menceritakan segala pengalaman masa lalunya dalam ritual ini sehingga akan membentuk pola pemikiran kepada generasi sekarang. Generasi baru yang datang pun akan mendapatkan cerita yang sama dan melihat secara langsung seremonial yang ada di pura, bersama dengan kelompok dan anggota keluarganya sehingga mereka mengidentifikasi dengan pura dan segenap seremonialnya. Tatanan upacara beserta tatanan gotong royong dan solidaritasnya, membentuk norma yang baku sehingga terus berlangsung sampai generasi terbaru. Pada perkembangan sosial-religius yang ada di Bali, meskipun terpaan globalisasi demikian deras terjadi, akan tetapi norma-norma untuk melaksanakan upacara di pura maupun norma gotong-royongnya, tidak terlalu mengalami perubahan. Di banjar-banjar pakraman di Denpasar maupun Badung bagian selatan di mana industri pariwisata demikian tumbuh pesat, masyarakat tetap melakukan acara melasti menjelang hari raya Nyepi. Sebelumnya, dilakukan berbagai kegiatan gotong-royong untuk mendukung ritual tersebut.

Identifikasi terhadap pura tersebut demikian kuat, apalagi kemudian pura tersebut dikaitkan dengan berbagai golongan yang memilikinya. Identitas formal seperti pelekatan sosial terhadap keturunan, 
kelompok kasta, kelompok ekonomi, sampai dengan kekeluargaan, membuat identititas pura di Bali semakin kental. Akibatnya, apabila terjadi gangguan terhadap identitas itu, maka akan muncul krisis yang bisa memicu konflik. Konflik ini menjadi kuat dan terbuka karena didorong oleh adanya solidaritas tersebut. Solidaritas mekanis akan menjadi solidaritas lain ketika muncul adanya gangguan terhadap identitas tersebut.

Berbicara mengenai perubahan sosial di Bali, tidak bisa dilepaskan dari kenyataan bahwa daerah ini menjadi tujuan pariwisata utama di Indonesia. Setelah krisis ekonomi menerpa Indonesia pada tahun 1997, sangat terasa bahwa andalan utama perekonomian Indonesia ada pada sektor pariwisata. Dorongan investasi pariwisata tersebut sangat besar karena pada akhirnya memunculkan hotel-hotel baru yang bertaraf internasional. Hotel-hotel bertaraf internasional yang berbintang lima itu, pada akhirnya memunculkan tuntutan pekerjaan yang tinggi dan profesional. Di Bali, pusat pembangunan hotel ditempatkan di Nusa Dua. Proyek ini sebenarnya mulai dilirik sejak dekade 70-an oleh investor. Pada waktu itu, tanah-tanah yang strategis dipatok oleh oknum pemerintah yang kemudian dibeli oleh investor. Penduduk yang mata pencahariannya sebagai nelayan, petani jagung dan petani kacangkacangan tidak berani bertindak dengan sikap dari oknum pemerintah tersebut (Sirtha 2008:139). Tahun 1978, BTDC (Bali Tourism Development Corporation) mempunyai otoritas untuk mengelola kawasan Nusa Dua. Sejak saat itulah kemudian laju pariwisata di Bali menjadi sangat pesat. Di samping berkembangnya Nusa Dua sebagai kawasan pariwisata baru, kawasan lainnya di Bali seperti Sanur dan Kuta juga semakin padat didatangi pengunjung. Di Kuta, komposisi pedagang yang beroperasi mengalami banyak perubahan. Tahun 2008 pedagang dari luar daerah memadati kawasan Kuta. Menurut catatan Pitana tahun 2000, komposisi pedagang di Kuta dkuasai oleh pendatang dari Sumatera (38\%), Jawa (35\%), Madura (4\%), Lombok (3\%), sementara pedagang lokal hanya menguasai 20 persen (Sirtha 2008:131). Perkembangan ini jelas memperlihatkan bagaimana perubahan sosial yang terjadi di daerah pariwisata utama di Bali.

Pariwisata sesungguhnya telah dimulai ketika bandara internasional Ngurah Rai diresmikan tahun 1971. Beroperasinya bandara internasional ini, turis-turis dari manca negara langsung bisa masuk ke Bali. Inilah yang memancing tumbuhnya berbagai perubahan. Di Kuta muncul diskotik yang juga dikunjungi oleh anak-anak muda Bali. Ubud yang sebelumnya dipandang sebagai daerah seni yang sejuk, tidak berpenduduk padat, secara perlahan mulai tampak kepadatannya. Yang lebih krusial lagi adalah mulai terlihat masyarakat Bali lebih mementingkan kegiatan kepariwisataan dibanding dengan proses kreativitas budaya sebagai ciri khas kebudayaan Bali. Munculnya banyak hotel-hotel di Bali, makin banyak membuat generasi muda yang lebih tertarik bekerja di sektor perhotelan. Ini dipandang membuat kreativitas-kreativitas kebudayaan mulai memudar.

Perlahan tapi pasti, perkembangan pariwisata di Bali juga memperlihatkan pengaruhnya tehadap eksistensi pura. Secara tradisional, pura berada pada tempat-tempat yang dipandang sakral oleh masyarakat. Misalnya pura ada di batu karang, di tengah hutan atau di dataran tinggi. Tujuan dari pendirian pura di lokasi-lokasi tersebut tidak lain untuk mempertahankan pura dari gangguan hal-hal di luar kemampuan manusia. Oleh masyarakat, tempat-tempat seperti itu dipandang suci. Pura Tanah Lot atau Uluwatu misalnya, berada di tengah karang kuat di tepi laut. Dari sisi lokasinya, posisi yang berada di tengah batu karang jelas merupakan tempat yang kuat dan sukar dijamah oleh mereka yang ingin berperilaku jahat. Pencurian di Pura Tanah Lot misalnya, tidak akan bisa terjadi karena pura ini berada di tengah karang di tengah laut. Demikian pula pura yang ada di tengah hutan (misalnya Pura Batukaru, Tabanan), akan sulit dijamah oleh manusia yang bermaksud jahat. Mendirikan pura di tengah hutan juga membuat kosentrasi lebih terkendali pada saat sembahyang.

Pariwisata dalam perkembangannya ternyata mempunyai sisi yang bertolak belakang dengan keberadaan pura tersebut. Pertama, dari sisi arah konsepsional, pariwisata di Bali dikembangkan dari dasar pariwisata budaya, sedangkan kebudayaan Bali berangkat dari filosofi Hindu. Segala hasil kreativitas, tindak-tanduk, dan hubungan sosial di Bali dilandasi oleh filosofi Hindu. Kreativitas seni yang muncul di Bali, tidak bisa lain berupa hasil kreativitas yang dilakukan oleh masyarakat secara penuh dan tulus ikhlas dipersembahkan untuk Sang Hyang Widhi (Tuhan), yang mana nilai-nilai ketulusan dan keikhlasan dapat dilihat di Pura. Ukir-ukiran paling bagus jika dilihat ada di pura. 
Demikian pula tari-tariannya. Seni Kecak sesungguhnya berasal dari tarian sakral yang hanya boleh dipentaskan di pura. Etika sosial paling mendasar bagi masyarakat Hindu Bali, yaitu Tat Twan Asi (saya adalah engkau), berasal dari filosofi Hindu. Demikian juga dengan hukum kharma phala yang menjadi pedoman bertingkah laku, berdasar dari dasar ajaran Hindu.

Pariwisata yang berbasis budaya tersebut justru melihat hal-hal yang bersifat otentik, asli, dan murni berada di wilayah-wilayah budaya tersebut. Wilayah budaya yang menjadi pusat adalah tempat sembahyang. Karena itu pariwisata akhirnya terarah kepada kompleks-kompleks pura yang ada di Bali. Setiap pura yang terkenal di Bali justru menjadi obyek pariwisata. Ritual yang dilakukan di pura justru menjadi sajian menarik bagi para turis. Ritual upacara agama yang sesungguhnya suci bagi masyarakat Hindu di Bali, justru menjadi tontonan yang menarik bagi para turis. Mereka belum pernah melihat peristiwa demikian di daerah asalnya sendiri. Dari ketertarikan itulah kemudian turis, dengan berbagai macam ragamnya, masuk ke lingkungan pura. Ada pertentangan di sini karena di saat masyarakat melakukan ritual keagamaan yang khusyuk, justru menjadi tontonan bagi turis. Kompleks-kompleks pura yang suci dipandang menjadi cemar karena para turis itu berpakaian sesuai dengan selera mereka menuju lingkungan yang dipandang suci. Konflik akibat dari persoalan ini diatasi dengan adanya pelarangan bagi turis untuk masuk ke areal suci pura, yaitu tempat yang dipandang sebagai lokus tempat bersemayamnya manifestasi Tuhan. Turis yang datang juga diwajibkan mengenakan kain yang dipandang sopan untuk memasuki lingkungan pura.

Kedua, pariwisata jelas-jelas bersinggungan dengan bisnis dan segala aspek ekonomi lainnya. Karena itu rasionalitas berupa mencari manfaat maksimal dalam pariwisata ini tidak bisa dihindari. Dalam bidang ekonomi, manfaat maksimal itu bisa diterjemahkan mencari keuntungan maksimal dengan cara-cara paling efektif (Ritzer \& Goodman 2007:394). Prinsip inilah yang kemudian masuk ke dalam pariwisata budaya di Bali. Karena budaya di Bali itu bersumber kepada filosofi agama Hindu dengan berbagai kreasinya, maka salah satu pusat kebudayaan itu ada di Pura. Bisnis menangkap pariwisata Bali itu dengan langkah-langkah yang paling efektif adalah dengan langsung mendirikan bisnis pariwisata pada tempat yang paling berdekatan dengan pura. Pendirian tempat bisnis pariwisata ini akhirnya menjadi kontroversi tersendiri. Pasar tempat menjajakan cinderamata didirikan dekat dengan lokasi pura. Bahkan hotel pun berdiri dekat dengan pura. Ini menimbulkan pertentangan dengan prinsip budaya Bali, yang menentukan jarak tertentu dengan lokasi tempat sembahyang. Konflik paling besar yang terjadi antara bisnis pariwisata dengan tempat suci adalah saat pendirian Hotel Bali Nirwana Resort di Tanah Lot. Bagi pengusaha, mendirikan hotel berdekatan dengan wilayah pura ini merupakan manifestasi dari efektivitas dan keuntungan maksimal (Balipost 2013:6). Turis langsung mendapatkan tempat di wilayah kultural dan berdekatan dengan pantai. Mereka tidak perlu waktu yang banyak untuk mendapatkan wilayah pariwisata.

Budaya ritual religius Bali juga menempatkan laut sebagai tempat suci karena ritual juga harus melibatkan laut sebagai manifestasi Dewa Wisnu dan penyucian segenap perangkat upacara. Pada pihak lain, laut dalam konteks pariwisata Bali memiliki kelebihan tersendiri karena mempunyai pantai yang berpasir putih. Disini muncul konflik antara kultural Bali dengan para pengelola bisnis pariwisata. Sebagai korporasi yang bergerak pada bidang bisnis, sekali lagi manfaat maksimal harus didapatkan. Karena itulah berbagai hotel kemudian bermunculan di pantai. Kondisi seperti ini sangat bertolak belakang dengan apa yang dimaknai oleh umat Hindu. Banyaknya hotel di pantai membuat jalan menuju pantai semakin tidak bebas.

Konflik yang muncul disini adalah banyaknya kritik terhadap keberadaan wisatawan di pantai, pada saat umat Hindu melaksanakan ritual agama di laut. Pemandangan kontroversial terjadi karena di saat masyarakat Hindu menuju pantai dengan pakaian adat untuk bersembahyang, justru di pantai ada wisatawan berjemur dengan memakai pakaian bikini. Fenomena ini sesungguhnya melukai perasaan umat Hindu di Bali. Baik pura sebagai tempat sembahyang maupun pantai sebagai bagian dari ritual persembahyangan bagi masyarakat Hindu di Bali menghadapi penodaan nilai-nilai kultural dan religius karena harus berhadapan dengan industri pariwisata. Industri pariwisata ini di Bali justru mengambil sektor paling dasar dalam kehidupan masyarakat sebagai daya tariknya, yaitu kebudayaan. 
Penodaan terhadap nilai-nilai kultural religius ini menimbulkan rasa tertekan dan konflik antara pihak hotel dengan masyarakat sering muncul akibat adanya persoalan ini.

Industri pariwisata di Bali memberikan sumbangan besar bagi perekonomian Bali. Hal ini harus dipahami karena pertumbuhan perekonomian Bali banyak digerakkan dari sektor pariwisata. Dalam hal kunjungan pariwisata menuju daerah-daerah pariwisata, sumbangan yang paling nyata didapatkan adalah mendapatkan pemasukan langsung dari karcis masuk serta karcis parkir. Pada daerah-daerah seperti ini, hasil sumbangan tersebut disamping merupakan pendapatan daerah, juga sumbangan kepada banjar bersangkutan dan kemudian banjar akan memberikan sumbangan kepada perbaikanperbaikan tempat sembahyang (pura). Akan tetapi, konsekuensi yang menjadi kenyataan dalam perkembangan pariwisata di Bali, adalah munculnya ikutan dari industri pariwisata, yaitu hotel dan restoran. Inilah sesungguhnya yang memberikan sumbangan positif bagi perkembangan industri pariwisata di Bali. Pajak hotel dan restoran inilah yang kemudian kembali disumbangkan kepada masyarakat.

Secara historis, perkembangan pariwisata Bali tidak bisa dilepaskan oleh budaya masyarakat. Inti dari pariwisata budaya itu adalah agama Hindu Bali yang menjadi keseharian masyarakat. Pusat-pusat perkembangan budaya tersebut adalah pura dengan ruang kreatifnya ada di seluruh bagian pura, yakni utama mandala, Madya Mandala dan Nista Mandala. Tari-tarian serta berbagai ritual berlangsung di utama mandala, pusat aktivitas untuk mengkreasi kesenian itu ada di madya mandala dan nista mandala. Dengan demikian, seluruh bagian dari pura ini, tidak hanya menjadi pusat persembahyangan tetapi menjadi kreativitas budaya. Satu lagi bagian yang menjadi pusat kreativitas budaya, termasuk munculnya pemikiran-pemikiran itu, adalah Bale Banjar. Bisa dikatakan bahwa pura mempunyai sumbangan besar (juga bale banjar) ${ }^{1}$ terhadap perkembangan pariwisata ini. Logikanya pusat-pusat kreativitas ini tidak boleh stagnan. Dalam konsepsi sosial di Bali, pura yang paling utama itu adalah Pura Khayangan Tiga, yang dilindungi dan diampu oleh Desa Pakraman. Setiap desa pakraman pasti mempunyai pura Khayangan Tiga, karena itu menjadi persyaratan dari berdirinya Desa Pakraman.

Pemerintah provinsi Bali menyadari bahwa pihak yang paling mempunyai sumbangan kreativitas terhadap pariwisata di Bali adalah masyarakat dengan pusat kreativitas itu ada di pura. Desa pakraman bisa dikatakan sebagai wilayah komunitas yang paling dasar dalam budaya dan sistem sosial di Bali. Untuk menghidupakan kreatifitas dan memenuhi hak mereka, maka pemerintah daerah provinsi Bali kemudian "mengembalikan" uang hasil pariwisata itu yang didapatkan melalui pajak hotel dan restoran kepada desa pakraman. Tujuannya adalah memelihara semangat kreatifitas tersebut agar budaya itu tetap dinamis dan berkembang. Pemerintah daaerah provinsi Bali memberikan bantuan sumbangan uang puluhan juta sampai ratusan juta kepada setiap desa pakraman dengan peruntukan pembangunan. Akhir-akhir ini, jumlah tersebut meningkat menjadi 100 juta. Oleh desa pakraman, jumlah uang tersebut dipakai untuk pembangunan di desa pakraman. Demi representasi dari pembangunan tersebut, sebagian besar desa pakraman mengarahkan pembangunan tersebut untuk memperbaiki tempat sembahyang atau yang berkaitan dengan tempat persembahyangan. Sebagian juga memakai uang tersebut untuk perbaikan bale banjar. Pura dan bale banjar adalah pusat-pusat kreativitas kebudayaan pada masyarakat Hindu di Bali.

Ada beberapa faktor yang menyebabkan munculnya konflik. Konflik muncul karena adanya keinginan kelompok untuk menguasai sumber daya lainnya. Atau ada kelompok yang khawatir dengan eksistensinya yang dikuasai oleh pihak lain, seperti yang diutarakan Maurice Duverger (Rauf 2001:50). Tetapi, konflik horizontal yang muncul dalam masyarakat disebabkan oleh perberadaanperbedaan pendapat yang terjadi pada masyarakat tersebut. Masyarakat mempunyai kepentingan tertentu, mempunyai identitas tertentu yang dianggap bukan saja cerminan religiusitas tetapi juga nilai, keyakinan dan kebudayaan kelompok masyarakat. Konflik mempunyai sisi yang kelam karena pihak yang berselisih tidak saja menginginkan sesuatu tetapi juga berupaya memojokkan, merugikan bahkan saling menghancurkan (Wirawan 2012:92).

\footnotetext{
${ }^{1}$ Bale Banjar adalah bangunan umum yang dimiliki oleh komunitas kumpulan keluarga.
} 
Seperti yang telah diungkapkan sebelumnya, pura mempunyai identitas bagi kelompok yang mengemongnya. Dalam hubungan dengan agama, pura merupakan tempat sembahyang bagi masyarakat yang beragama Hindu. Sementara apabila dikaitkan dengan masyarakat Hindu, pura juga merupakan identitas bagi kelompok-kelompok yang ada, seperti kelompok pasek, brahmana, ksatria, keturunan dan sebagainya. Karena itulah pura sangat lekat dengan identitas kelompok. Kelekatan ini mempunyai nilai kritis, berupa konflik antar kelompok. Ketika pemerintah provinsi Bali mengucurkan dana yang berasal dari pajak hotel dan restoran, bagi desa pakraman pemanfaatan terbesar dari uang tersebut adalah untuk membenahi dan melanjutkan pembangunan di pura. Di lihat dari sisi sejarah perkembangan pariwisata, pembangunan dan perbaikan pura ini signifikan karena pura menjadi tempat munculnya berbagai macam kreatifitas dan karya-karya budaya. Tetap berlangsungnya kreativitas tersebut, maka budaya akan terus berkembang dan pariwisata yang berbasis budaya juga akan bisa terus berkembang. Jika dilihat dari sisi konsepsi pemikiran masyarakat, pembangunan pura ini dipandang sebagai upaya untuk melengkapi kekurangan-kekurangan bagunan yang ada.

Namun di sisi lain, bantuan kepada desa pakraman yang berasal dari pajak hotel dan restoran tersebut, pada kenyataannya menimbulkan keinginan-keinginan untuk membentuk desa pakraman baru. Jumlah dana yang diberikan kepada desa pakraman yang berasal dari pajak hotel dan restoran dari tahun ke tahun selalu meningkat yang pada awalnya berjumlah puluhan juta rupiah, kini menjadi 100 juta rupiah (Wawancara dengan Gunadnya 2013). Uang ini tentu memberikan daya tarik tersendiri. Desa pakraman yang keanggotaannya kebanyakan terdiri dari lebih dari satu banjar pakraman, memerlukan berbagai aturan yang mengikat banjar tersebut sebagai konsekuensi masuk dalam desa pakraman. Akibatnya, beberapa banjar pakraman merasa terikat dengan banjar-banjar lain yang ada dalam satu desa pakraman tersebut. Pemahaman bahwa untuk membentuk desa pakraman itu memerlukan perlengkapan yang disebut dengan Khayangan Tiga, membuat beberapa banjar menginginkan untuk terpisah dan membentuk desa pakraman sendiri. Atau satu banjar membentuk desa pakraman sendiri. Ini tidak bisa dilepaskan dari kenyataan bahwa banyak banjar-banjar di Bali yang telah memiliki kuburan dan Pura Dalem sendiri. Untuk membentuk desa pakraman, maka hanya diperlukan dua tempat sembahyang lagi, yaitu Pura Puseh dan Pura Desa. Dua pura inipun bisa dibuat dalam satu kompleks.

Keinginan inilah yang kemudian menimbulkan konflik diantara anggota desa pakraman. Konflik itu terjadi karena beberapa hal. Dalam kasus yang terjadi di Banjar Pakraman² Pangkungkarung, Kecamatan Kerambitan, Kabupaten Tabanan, konflik terjadi karena ketidaksetujuan dari desa pakraman induk, yaitu Desa Pakraman Bedhe. Banjar Pakraman Pangkungkarung, diawali oleh ketidaktahuannya dengan kesepakatan dan aturan yang ada bahwa pemekaran desa pakraman sudah tidak dibolehkan, Banjar Pakraman Pangkungkarung telah mendirikan pura yang disebut pura puseh dan pura desa (Bale Agung). Pura ini telah menjadi pelengkap dari pura dalem yang dimiliki oleh Banjar Pakraman Pangkungkarung. Dengan adanya pura tersebut, Banjar Pakraman Pangkungkarung sebenarnya telah memenuhi syarat menjadi Desa Pakraman. Karena dipandang tidak mematuhi aturan dan kesepakatan yang telah ditentukan oleh Desa Pakraman Bedhe ${ }^{3}$ dan lembaga Majelis Utama Desa Pakaraman Bali, maka terjadilah konflik yang berkepanjangan. Banjar Pakraman Pangkungkarung tidak dibolehkan berkembang menjadi desa pakraman (Nala 2013). Di banjar pakraman ini ada dua kelompok, masing-masing yang mendukung berkembangnya menjadi desa pakraman dan pihak yang menolak. Konflik akhirnya membuat Banjar Pakraman Pangkungkarung terpecah dua, masing-masing menjadi Banjar Pakraman Pangkungkarung, yakni mereka yang menolak munculnya desa pakraman, dan Banjar Pakraman Pangkungkarung Gede, bagi mereka yang mendukung adanya pemekaran.

\footnotetext{
${ }^{2}$ Banjar pakraman adalah komunitas tradisionil Bali yang merupakan kumpulan dari keluarga.

${ }^{3}$ Desa pakraman merupakan komunitas yang telah berhasil membangun Pura Khayangan Tiga. Komunitas ini bisa terdiri dari satu banjar pakraman atau gabungan beberapa banjar pakraman. KhayanganTiga merupakan pengikatnya.
} 
Beberapa pendapat menyebutkan bahwa konflik yang terjadi pada Banjar Pakraman Pangkungkarung ini disebabkan oleh adanya bantuan uang berupa pajak hotel dan restoran yang diberikan kepada desa pakraman. Dalam sepuluh tahun terakhir, jumlah bantuan itu meningkat terus, mulai dari 25 juta lima tahun yang lalu menjadi 100 juta rupiah tahun 2013 ini. Beberapa banjar pakraman yang ada di sekitar Banjar Pakraman Pangkungkarung, yaitu Banjar Pakraman Selingsing, Penyalin, Samsam, Kutuh Kelod, Kutuh Kaja telah meningkatkan statusnya menjadi desa pakraman, dimana komposisinya hanya teridiri dari satu banjar pakraman. Seluruh banjar pakraman tersebut telah melengkapi Pura Dalem yang dimilikinya dengan membangun Pura Puseh dan Pura Desa sehingga berhak menyandang predikat sebagai desa pakraman. Dan itu terjadi sebelum adanya ketentuan dari Majelis Utama Desa Pakraman yang menghentikan pembentukan desa pakraman baru. Dengan bantuan uang sebanyak 100 juta rupiah tersebut, pembangunan yang berlangsung di desa pakraman ini menjadi pesat. Hal inilah yang menjadi dugaan bahwa Banjar Pakraman Pangkungkarung menginginkan memisahkan diri dari desa pakraman induk, dan membentuk menjadi desa pakraman sendiri.

Dalam kasus yang terjadi di Desa Pakraman Ketandan Gianyar, konflik yang melibatkan Pura Dalem Rsi, disebabkan oleh pembangunan oleh salah satu kelompok di pura tersebut. Pembangunan itu dilakukan atas bantuan dari pajak hotel dan restoran dari Desa Pakraman Ketandan sejumlah 50 juta rupiah, pada tahun 2011. Pura ini sesungguhnya diampu oleh dua komunitas yang saling mempunyai hubungan persaudaraan. Dua kelompok bersaudara itu adalah Kelompok masyarakat Brahmana dari Griya Ketandan dan kelompok masyarakat Brahmana dari Desa Pakraman Tegalinggah (Yadnya 2012). Kelompok Brahmana dari Ketandan telah mendapatkan status sebagai Desa Pakraman yang menjadikan Pura Dalem Rsi ini sebagai pelengkap dari Pura Khayangan Tiga, selain Pura Puncak Manik sebagai Pura Puseh dan Pura Desa. Padahal Pura Dalem Rsi tersebut dimiliki juga oleh kelompok Brahmana dari Desa Pakraman Tegallinggah (Sutri 2012). Konflik ini berlangsung secara terbuka, dimana terjadi saling serang, lempar batu antara kedua kelompok Brahmana tersebut. Kelompok Brahmana dari Tegalinggah yang sebelumnya tidak masuk dalam Desa Pakraman Tegalinggah, akhirnya masuk menjadi anggota desa pakraman tersebut. Dan kelompok Brahmana Ketandan membuat Pura Dalem sendiri. Dengaan demikian, konflik terjadi karena ada penguasaan atas pura tersebut yang dipandang tidak pantas oleh kelompok lainnya.

Di wilayah Pakudui, Tegalalang, Ubud, konflik juga melibatkan pura Khayangan Tiga. Akan tetapi, konflik ini tidak berawal dari sumbangan pajak hotel dan restoran (Samudra 2012). Sebagai desa pakraman, Pakudui terdiri dari dua tempekan (kelompok), yaitu Tempekan Kangin dan Tempekan Kawan. Tahun 2010 terjadi perselisihan diantara kedua tempekan tersebut yang bersumber dari dana hasil penyewaan tanah. Sebuah tempat wisata yang berada di ujung barat Desa Pakraman Pakudui disewa oleh turis Amerika Serikat. Pemilik dari tanah ini adalah Tempekan Kangin (kelompok wilayah timur). Uang hasil sewa tersebut ternyata kemudian hanya dikuasai oleh Tempekan Kangin tanpa memberikan kepada Tempekan Kawan, meski keduanya telah masuk ke dalam kesatuan Desa Pakraman Pakudui. Bentuk konfliknya adalah penghadangan jenazah warga Tempekan Kangin menuju kuburan. Inilah yang kemudian membuat Tempekan Kangin ingin membentuk desa pakraman sendiri. Pura Puseh dan Bale Agung dikuasai oleh Tempekan Kangin. Dalam kesepakatan antara kedua belah pihak, Tempekan Kangin akan membuat kuburan sendiri. sedangkan Tempekan Kawan(kelompok barat) menguasai Pura Desa, Pura Puseh yang sudah ada serta Kuburan. Pura Bale Agung yang dikuasai oleh Tempekan Pakudui Kangin, dalam pandangan mereka berdasarkan cerita dari leluhurnya, telah mengandung unsur Pura Puseh, sehingga hanya memerlukan pembangunan Pura Dalem saja. Dengan demikian konflik yang melibatkan pura ini disebabkan oleh adanya kesalahtafsiran dalam kepemilikan wilayah (Taksu 18 September 2010).

Di Banjar Pakraman Gereseh, Kecamatan Marga, Tabanan, konflik yang melibatkan pura terjadi sebagai akibat dari kepemilikan tanah dari warga tempat berdirinya pura tersebut. Pihak pemilik tanah, yang didasarkan atas kepemilikan sertifikat, mengunci tempat sembahyang tersebut. Inilah yang kemudian menimbulkan kemarahan masyarakat (Balipost 29 Juni 2013). Bentuk konflik adalah penyerangan rumah pihak pemilik tanah, dengan menghancurkan tempok dan genting dari rumah tersebut. 


\section{Simpulan}

Keberadaan pura sangat terkait dengan identitas dari masyarakat pengemong (pengampu) pura yang bersangkutan. Masyarakat Bali mempuyai keberagaman identitas yang berasal dari keturunan, kasta maupun struktur sosial. Identitas tersebut diikuti oleh solidaritas sosial mekanis yang demikian tinggi. Artinya kelompok masyarakat yang mengampu pura tersebut disamping dilengkapi dengan identitasnya masing-masing, juga (pada akhirnya) dilengkapi dengan solidaritas mekanis tersebut. Identitas dan solidaritas inilah bisa melahirkan tindakan masif yang sangat tergantung dari kondisi yang dihadapi masyarakat saat itu.

Secara umum, masyarakat Bali saat ini menghadapi perubahan sosial yang besar. Perubahan sosial tersebut dimulai dari perkembangan pariwisata Bali yang pesat. Inti pariwisata Bali adalah pariwisata budaya yang mempunyai pusat di pura, yaitu tempat sembahyang. Konsekuensi paling besar dari konsepsi pariwisata ini adalah menyentuh ranah pura itu, baik lingkungan maupun kemudian seremonialnya. Disamping memberikan pengaruh besar kepada perekonomian, pariwisata juga pada akhirnya memberikan pengaruh degradasi lingkungan, termasuk lingkungan pura.

Disinilah kemudian muncul konflik. Pertama konflik akibat dari terpengaruhnya lingkungan pura oleh pariwisata. Ini akan menimbulkan ketersinggungan terhadap identitas pengemong pura dan solidaritasnya yang kemudian menimbulkan perlawanan kepada para penggerak pariwisata. Kedua, muncul konflik internal di kalangan masyarakat Bali. Ini disebabkan karena perkembangan perekonomian yang diakibatkan oleh pariwisata, juga memberikan sumbangan kepada desa pakraman, lokus dari berkembangnya pariwisata budaya. Jumlah sumbangan ini cukup besar untuk ukuran Desa Pakraman di Bali. Maka, muncullah keinginan untuk membentuk Desa Pakraman baru. Munculnya Desa Pakraman baru ini menimbulkan masalah secara internal. Terdapat benturan identitas kelompok antara pihak yang menyetujui pembentukan Desa Pakraman dengan pihak yang tidak menyetujui yang berujung pada terjadinya konflik.

Pura tidak menjadi penyebab konflik, juga tidak sebagai pemicu konflik akan tetapi menjadi sasaran dari kepekaan kelompok terhadap kepemilikannya. Penyelesaian konflik yang menyangkutkan tempat persembahyangan cukup sulit. Konflik akan bisa diselesaikan kalau lembaga yang lebih besar (superordinat) bersedia mengalah terhadap keadaan yang ada. Ini akan mengakibatkan dialog lebih konstruktif. Apabila tidak ada kesediaan mengalah dari masing-masing pihak, maka konflk itu akan menghasilkan perpecahan kelompok. Perpecahan ini permanen. Jika kondisi kedua itu tidak tercapai maka konflik akan terpelihara terus-menerus, berpotensi setiap waktu pecah menjadi konflik terbuka.

\section{Daftar Pustaka}

Balipost, 30 Juni 2013--- Judul Artikel “Trauma, Korban akan Mengadu ke Komnas Ham”, hal 2.

Balipost, 7 Juli 2013--- Judul Artikel "Usulan Damai Masih Buntu”, hal 2.

Balipost (2013) Balipost, 29 Juni, Pura di Gembok: Massa Rusak Rumah Warga, hal 4.

Berger PLH (ed)(1994) Langit Suci: Agama sebagai Realitas Sosial. Jakarta: LP3ES.

Gunadnya GP (2012) [Personal communication] 16 September.

Nakatani A (2005) Ritual as work: The invisibility of women's socio-economic and religious roles in a changing Balinese Society. Dalam: Reuter\& Thomas A (eds). Inequality, Crisis and Social Change in Indonesia: The Muted Worlds of Bali.London: RoutledgeCurzon.

Nordholt HSPY (ed)(2009) The Spell of Power: Sejarah politikBali 1650-1940. Denpasar: Pustaka Larasan.

Nurhashim (ed) (2005) Konflik antar elit politik lokal dalam pemilihan kepala daerah. Yogyakarta: Pustaka Pelajar.

Purwita IBP (1993) Desa adat pusat pembinaan Kebudayaan Bali. Denpasar: Upada Sastra Rauf. Nala G (2013) [Personal communication] 26Agustus. 
Rauf M (2001) Konsensusdan konflik politik: Sebuah penjajagan teoritis. Jakarta:

DirektoratJenderalPendidikanTinggiDepartemenPendidikanNasional.

Ritzer G \& Goodman DJ (2007) Teori sosiologi modern. Jakarta: Kencana Prenada Media.

Samudra (2012) [komunikasi pribadi] 8 Februari.

Sila G (2013) [komunikasi pribadi]26 Agustus.

Sirtha IN (2008) Aspek Hukum dalam Konflik Adat di Bali, Denpasar: Udayana University Press.

Sulastri P(2012) [komunikasi pribadi] 7 April.

Sutri, IM (2012) [komunikasi pribadi] 7 April.

Tohjaya INGB (1991) Riwayat Mpu Kuturan. Denpasar: Ria.

Von Benda-Beckmann F \& von Benda Beckman K (2011) Identitas Perselisihan di Minangkabau.

Dalam: Ramstedt, Martin, Ibnu Thufail, Fajar (eds). Kegalauan Identitas: Agama, Etnisitas dan Kewarganegaraan Masa Pasca-Orde Baru. Jakarta: Grasindo.

Warren C (1993) Adat and Dinas: Balinese Communities in the Indonesian State.Kuala Lumpur: Oxford University Press.

Wirawan IB (2012) Teori-teori sosial dalam tiga paradigma. Jakarta: Kencana Prenada Media Group. Yadnya IB (2012) [komunikasi pribadi] 10 April. 